\title{
Egy deréktáji fájdalommal kapcsolatos betegségspecifikus tudást felmérő külföldi kérdőív hazai, magyar nyelvü validálása
}

\author{
Kovács-Babócsay Bianka ${ }^{1}$ - Makai Alexandra ${ }^{1}$ \\ Szilágyi Brigitta ${ }^{1}$. Tardi Péter ${ }^{1}$. Ács Pongrác dr. ${ }^{1}$. Velényi Anita ${ }^{2}$ \\ Rébék-Nagy Gábor dr. ${ }^{3}$ - Járomi Melinda dr. ${ }^{1}$

\begin{abstract}
${ }^{1}$ Pécsi Tudományegyetem, Egészségtudományi Kar, Fizioterápiás és Sporttudományi Intézet, Pécs
${ }_{2}^{2}$ Pécsi Tudományegyetem, Általános Orvostudományi Kar, Klinikai Központ, Idegsebészeti Klinika, Pécs

${ }^{3}$ Pécsi Tudományegyetem, Általános Orvostudományi Kar, Egészségügyi Nyelvi és Kommunikációs Intézet, Pécs
\end{abstract}

Bevezetés: A nemzetközi szakirodalomban számos, betegségspecifikus tudást mérő kérdőív ismert, mely a betegek életminőségét, állapotuk progresszióját, funkcionális statusukat vizsgálja. Magyar nyelven kevés, a betegségspecifikus tudás mérésével kapcsolatos kérdőívet validáltak.

Célkitüzés: Célunk volt a Low Back Pain Knowledge Questionnaire (LKQ) magyar nyelvre fordítása, megbízhatóságának és validitásának vizsgálata.

Módszer: A felmérésben 218 fö vett részt (krónikus low back pain [derékfájdalom-] szindrómás betegek, egészségügyi dolgozók, egészségügyi ismeretekkel nem rendelkezők). Átlagéletkor: 34 (18-64) év. A Maciel és mtsai által 2009ben megalkotott LKQ fordítását és validálását Beaton és mtsai 2000-ben megfogalmazott hatlépcsős elve szerint végeztük. A kérdőív belső konzisztenciáját Cronbach-alfa-érték-számítással mértük fel. A kérdőív külső validálását Roland-Morris-index segítségével végeztük. A megismételhetőségi vizsgálatot teszt-reteszt módszerrel Spearman-féle korrelációs koefficienssel vizsgáltuk.

Eredmények: A kérdőív megbízhatóságát vizsgáló Cronbach-alfa-érték 0,894 volt. A Roland-Morris-indexszel összehasonlítva az LKQ-val jól korreláló kérdőívet kaptunk $(\mathrm{R}=-0,393)$. A kérdőív teszt-reteszt vizsgálati eredménye $(\mathrm{R}=0,541-0,795, \mathrm{p}<0,050)$ mérsékelt és megfelelő összefüggést mutatott.

Következtetés: Az LKQ magyar nyelvre fordított verzióját, a Derékfájdalommal kapcsolatos betegségspecifikus tudást felmérő kérdőívet (DTK) megbízható és valid tudásmérő eszköznek találtuk.

Orv Hetil. 2019; 160(42): 1663-1672.

Kulcsszavak: derékfájdalom, betegségspecifikus tudás, kérdőív-validálás

\section{The Hungarian translation and validation of the Low Back Pain Knowledge Questionnaire}

Introduction: Many disease-specific questionnaires, which analyze patients' functional status, quality of life or the progression of the disease, have been validated in Hungarian. The low back pain (LBP) patients' knowledge about their problem has not been measured by an officially validated Hungarian tool.

Aim: The aim of our study was to translate and validate the Low Back Pain Knowledge Questionnaire (LKQ) and to assess its validity and reliability.

Method: We used the translation-back translation method as the first step. Then we used a synthesis of the back translations reviewed by independent translators. We enrolled 218 people in our study: 101 of them were chronic LBP patients and 73 acute LBP patients. For the validation process, we used the Roland-Morris Disability Index to compare our questionnaire. We calculated Cronbach's alpha values and correlation coefficients.

Results: The Hungarian version of LKQ correlated well with the Roland-Morris Index and it proved to be a valid questionnaire (correlation coefficient: -0.393 ; Cronbach's alpha value 0.894). 
Conclusion: We found the Hungarian version of LKQ a valid and reliable tool to measure patients' knowledge about LBP. We recommend future studies should apply bigger and more homogenous populations to assess LBP diseasespecific knowledge in this country.

Keywords: low back pain, knowledge, education, questionnaires

Kovács-Babócsay B, Makai A, Szilágyi B, Tardi P, Ács P, Járomi M, Velényi A, Rébék-Nagy G. [The Hungarian translation and validation of the Low Back Pain Knowledge Questionnaire]. Orv Hetil. 2019; 160(42): 1663-1672.

(Beérkezett: 2019. március 19.; elfogadva: 2019. április 5.)

\section{Rövidítések}

$\mathrm{BMI}=($ body mass index $)$ testtömegindex $; \mathrm{cLBP}=($ chronic low back pain) krónikus derékfájdalom; DTK = Derékfájdalommal kapcsolatos betegségspecifikus tudást felmérő kérdőív; ETK = Egészségtudományi Kar; EULAR $=($ European League Against Rheumatism) Európai Reumaellenes Liga; KK = Klinikai Központ; LKQ = (Low Back Pain Knowledge Questionnaire) a Derékfájdalommal kapcsolatos betegségspecifikus tudást felmérő kérdő́iv eredeti neve; MRI = (magnetic resonance imaging) mágnesesrezonancia-képalkotás; PTE = Pécsi Tudományegyetem; $\mathrm{R}-\mathrm{M}$ = Roland-Morris; $\mathrm{RMI}=$ Roland-Morrisindex

Az eltérő nemzetiségú és kultúrájú klinikai kutatások száma ugrásszerúen növekszik, ezzel együtt megnőtt az igény, hogy az egészségi állapotot felmérő kérdőívek a forrásnyelven kívül (amely a leggyakrabban az angol) más nyelven is elérhetôvé váljanak [1].

Több hazai kutatásban korlátot jelent a nemzetközi kérdőívek validált, magyar fordítású verziójának hiánya. Ennek hiányában nehezen lehet összevetni a külföldi és magyar populáción végzett vizsgálatok eredményeit. Több betegséget érintôen validált mérési módszer áll rendelkezésünkre, ezek azonban az érintettek állapotát, betegségük progresszióját és életminőségét vizsgálják. Kálcza-Jánosi és mtsai a 24-Items Diabetes Knowledge Questionnaire magyar nyelvű validálásával már az érintetteknek a betegségükről rendelkező tudását kívánták mérhetővé tenni [2]. A betegoktatás a prevenció és a rehabilitáció fontos része. A rehabilitáció eredményesebb edukációs programokkal kiegészítve. A tájékozott, helyes ismeretekkel rendelkező beteg jobban megérti az őt érintő folyamatot, így könnyebben is tud aktívan részt venni a progresszió és a recidíva elleni küzdelemben.

A derékfájdalom a legtöbb embert érintő mozgásszervi fájdalom, a betegek tudását eddig mégis kevéssé vizsgálták. Tóth Klára és Tóthné Steinhausz Viktória 1998-ban dolgoztak ki egy gyermekeknek készült gerinciskola-programot „Porci Berci barátokat keres” címmel. Ebben játékos kérdőív formájában a gyerekeknek a helyesnek vélt testtartási és gerinchasználati szokásait is felmérték [3]. Fontos és hasznos lenne további, a mozgásszervi betegségekkel kapcsolatos tudás érvényes felmérése a felnőtt lakosságra adaptálva is.
Weckbach és mtsai 248 , gerincmútétre váró beteg tudását mérték fel többszörös feleletválasztós kérdốiv segítségével [4]. A kérdőív 10 alapkérdést tartalmazott a gerinc anatómiájáról, a gerincbetegségek tüneteiről és kezeléséról. Ezt egy német klinikán végezték 2013. január és június között. A 18 és 88 év közötti betegek a kérdések 32,6\%-ára tudtak helyes választ adni.

Sharafkhani és mtsai [5] egy Health Belief Model alapú oktatási programmal mérték fel ápolók tudását a krónikus derékfájdalom prevenciós lehetóségeiről. Négy 60 perces előadást hallgathattak meg az ápolók a derékfájdalom rizikótényezőirốl, komplikációiról, a prevenciós tevékenységek előnyeiről, valamint a fájdalommal való megküzdési lehetőségekről. A vizsgálati és kontrollcsoportban 50-50 fö vett részt. Az oktatás megkezdése előtti tudásfelmérés azt mutatta, hogy az ápolók tudása nem elegendő a cLBP megelőzéséhez egyik csoportban sem (a testtartásbeli javaslatok, anatómia, ergonómia területén). Az intervenció hatására szignifikánsan nôtt az ápolók tudása és a kérdőívben elért átlagpontszámuk is.

A betegek derékfájdalommal kapcsolatos specifikus tudását mérō, magyarul validált kérdő́iv még nem jelent meg a szakirodalomban.

Kutatásunk célja a Derékfájdalommal kapcsolatos betegségspecifikus tudást felmérő kérdőív (DTK), eredeti nevén Low Back Pain Knowledge Questionnaire magyarra fordítása, hazai validálása és ennek segítségével egészségügyi végzettségúek, egészségügyi ismeretekkel nem rendelkezők, illetve cLBP-betegek tudásának felmérése.

\section{Vizsgálati csoportok}

Keresztmetszeti vizsgálatunkban 218 fó (ebből 74 férfi) vett részt. Átlagéletkoruk 34 (min. 18, max. 63) év volt.

A felmérés során négy csoportot különböztettünk meg:

1) Krónikus derékfájdalommal élő, a PTE ETK Fizioterápiás és Sporttudományi Intézet gerinciskola-programján részt vett betegek, 54 fö (ebből 21 férfi), átlagéletkor: 40 (25-58) év.

2) Krónikus derékfájdalommal élő, gerinciskola- és más gerincedukációs programban nem részesült, a PTE 
KK Idegsebészeti Klinika fekvő betegei, 54 fő (ebből 26 férfi), átlagéletkor: 42 (26-63) év.

Beválasztási kritériumaink között szerepelt a 18-65 éves életkor, önkéntes részvétel, MRI-vel igazolt degeneratív lumbális patológia (porckorong-degeneráció, porckorongsérv, kisízületi arthrosis, canalis spinalis stenosis), derékfájás és/vagy lumboischialgia.

Kizártuk a nem magyar anyanyelvú, egyéb belgyógyászati, neurológiai, mozgásszervi társbetegséggel élőket, valamint a depresszióval, krónikusfájdalom-szindrómával élőket. Kizártuk a 35 feletti BMI-vel rendelkezőket.

3) Egészségügyi előképzettséggel/ismerettel nem rendelkező egészségesek, a PTE ETK Fizioterápiás és Sporttudományi Intézet adminisztratív munkatársai, 54 fó (ebből 21 férfi), átlagéletkor: 37 (18-56) év.

4) Egészségügyi végzettséggel rendelkező egészségesek, 54 fó (ebből 5 férfi), átlagéletkor: 22 (21-36) év.

Egészségügyi végzettségűnek tekintettük azokat a föiskolai vagy egyetemi végzettségü egészségügyi dolgozókat, akik foglalkozásukból adódóan találkozhatnak és kezelhetnek derékfájdalomtól szenvedő betegeket, tehát elsősorban orvosokat, gyógytornászokat és ápolókat.

A felmérést a Pécsi Tudományegyetem Klinikai Központjának Idegsebészeti Klinikáján és a Pécsi Tudományegyetem Egészségtudományi Karának Fizioterápiás és Sporttudományi Intézetében végeztük 2018 májusa és októbere között.

Kutatásunkhoz a Pécsi Tudományegyetem (PTE) Klinikai Központjának Regionális és Intézményi Kutatásetikai Bizottsága adott engedélyt. Ügyiratszám: $7389 / 2018$.

\section{Vizsgálati módszer}

\section{LKQ-kérdöin}

A brazil São Pauló-i egyetemen dolgozó Maciel és kollégái 2009-ben alkották meg és validálták az eredeti kérdőívet [6]. A Low Back Pain Knowledge Questionnaire 16 kérdésből áll. A kérdőív a derékfájdalommal élők tudását méri fel, így tartalmaz kérdéseket a gerinc anatómiájával kapcsolatban, valamint a gerincbetegségek prevenciós és terápiás lehetőségeiről. A kérdőívet eddig egyelőre csak Szaúd-Arábiában validálták Awwad és mtsai szintén cLBP-betegek körében [7].

Az LKQ-kérdőív 16 egyszeres vagy többszörös feleletválasztós kérdésből áll. A kérdéseket az alábbi három csoportra osztották a szerzők: 1-es, 6-os, 7-es, 8-as, 15ös kérdés: általános tudás (9 pont szerezhető), fogalmak: 2-es, 3-as, 4-es, 5-ös kérdés (4 pont szerezhető), terápia: 9-es, 10-es, 11-es, 12-es, 13-as, 14-es, 16-os kérdés (11 pont szerezhető). Így maximálisan 24 pontot érhetnek el a kitöltők. Az LKQ-kérdőívek kiértékelését az eredeti szerzők által megadott nemzetközi irányelvek alapján végeztük [8-13]. A kérdőívek kitöltését gyógytornász kol- légák felügyelték, akik előtt ismeretlen volt a kérdooív és a helyes válaszok.

A brit Martin Roland és Richard Morris által 1983ban Londonban megalkotott Roland-Morris (R-M)kérdőívet használtuk [14] az LKQ-val való összehasonlításhoz. A résztvevőkkel a Valasekék által magyarul validált és 2015-ben publikált Roland-Morris-féle derékfájás-funkciócsökkenési kérdőívet töltettük ki. A kérdőív 24 kijelentést tartalmaz az egyén mindennapi tevékenységeinek a derékfájdalom által korlátozott vonatkozásaival kapcsolatban. Ahányat igaznak ítél a kitöltő, annyi pontértéket kap. Minél magasabb a pontszám, annál rosszabb a gerinc funkcionális állapota.

\section{A kérdöin forditása és validálása}

Az LKQ-kérdőív magyar nyelvre fordítása és validálása a 2000-ben megfogalmazott hatlépcsős irányelv szerint $[1,15]$ történt: fordítás, szintézis, visszafordítás, előtesztelés, belsőkonzisztencia-vizsgálat, külső validálás más kérdőívvel. Első lépésként az angol nyelvű kérdőívet két verzióban magyarra fordítottuk egy laikus, egészségügyi ismeretekkel nem rendelkező, illetve egy gyógytornászvégzettségú fordítóval. A két magyar fordításból megszületett egy szintézis, melyet egy 30 fós, krónikus derékfájdalommal élő betegcsoporton előteszteltünk. Itt a problémát okozó kifejezéseket javítottuk. Így az alábbi fogalmakat, kifejezéseket cseréltük: „ágyéktáji” helyett „deréktáji”, „ülőidegzsába” helyett „alsó végtagba kisugárzó”, „gerincsérv” helyett „porckorongsérv”, „tumor” helyett „daganat”, „diabétesz” helyett „cukorbetegség”, „melyen keresztül közlekedik a gerincvelő” kifejezés helyett a "gerincvelő található”, „görcsoldó" helyett „izomlazító”, „kompresszió” helyett „nyomás”.

Az eredeti szerzőkkel történt egyeztetést követően a validáláshoz az általuk javasolt Roland-Morris-kérdőívet választottuk, amellyel összehasonlítva a külső validálást kívántuk végezni a magyarra fordított LKQ-kérdőívvel, mert más, a derékfájdalommal kapcsolatos betegségspecifikus tudást felmérő kérdőív nincs magyarul validálva.

Ezután a betegek írásos beleegyező nyilatkozatot tettek, majd az LKQ- és R-M-kérdőívet töltötték ki.

A statisztikai számításokat az SPSS 20.0 verziójú szoftverrel (IBM Corporation, Armonk, NY, Amerikai Egyesült Államok) végeztük. A kérdőív belső konzisztenciáját a Cronbach-alfa-érték számításával mértük fel, amely érték 0,7-től mondható megbízhatónak. A Roland-Morris-indexszel való korrelációt és a teszt-reteszt vizsgálatot a Spearman-féle korrelációs koefficienssel vizsgáltuk. A megismételhetőség vizsgálata egy 35 fós csoporttal, a teszt-reteszt módszerrel történt, és a statisztikai analízis során ismét Spearman-féle korrelációs koefficienst számítottunk.

Eredményeinket $\mathrm{p}<0,05$ esetén tekintettük szignifikánsnak. 


\section{Az alkalmazott gerinciskola-program felépitése}

Kutatásunkban 54 cLBP-beteg vett részt (átlagéletkor: 40 év), akik gerinciskola-program keretében betegoktatást is kaptak. A három hónapos program keretében hetente egyszer zajlottak a foglalkozások gyógytornász vezetésével. A fennmaradó heti hat alkalommal otthon gyakorolták a tanultakat napi 15 percben.

Részletes tematika:

1. hónap: gerincanatómia, gerinc-biomechanika, a gerincbetegségek kialakulása, a fájdalom oka.

2. hónap: a gerincvédelem szabályai, gerincbarát életmód, ergonómia, LBP-prevenciós lehetőségek, LBP-terápiás lehetőségek.

3. hónap: gerincbarát szabadidő, gerincbarát munkahely, gerincbarát sport.

\section{Eredmények}

\section{A kérdöin belső́konzisztencia-vizsgálatának eredményei}

A kérdőív megbízhatóságát Cronbach-alfa-értékek segítségével vizsgáltuk. Itt a kapott számadatok azt mutatják, hogy az LKQ megbízható, a kérdések jól korrelálnak egymással (Cronbach-alfa $=0,894)$ (1. táblázat). A kérdés csoportonkénti vizsgálatakor a fogalmak kérdéskörével az elfogadhatóság határán álló, mérsékelt megbízhatósági értéket kaptunk (0,672).

1. táblázat $\mid \mathrm{Az}$ LKQ-kérdőív belsőkonzisztencia-vizsgálatának eredményei Cronbach-alfa-számítással

\begin{tabular}{lcccc}
\hline & $\begin{array}{c}\text { Összes } \\
\text { kérdés } \\
(\mathrm{n}=16)\end{array}$ & $\begin{array}{c}\text { LKQ ÁT } \\
(\mathrm{n}=5)\end{array}$ & $\begin{array}{c}\text { LKQ F } \\
(\mathrm{n}=4)\end{array}$ & $\begin{array}{c}\text { LKQ K } \\
(\mathrm{n}=7)\end{array}$ \\
\hline $\begin{array}{l}\text { Cronbach-alfa-érték } \\
0,894^{*}\end{array}$ & $0,762^{*}$ & 0,672 & $0,764^{*}$ \\
$\begin{array}{l}\text { A 95\%-os megbízhatósá- } \\
\text { gi tartomány alsó értéke }\end{array}$ & 0,872 & 0,708 & 0,594 & 0,713 \\
$\begin{array}{l}\text { A 95\%-os megbízhatósá- } \\
\text { gi tartomány felsó értéke }\end{array}$ & 0,913 & 0,809 & 0,738 & 0,809 \\
\hline
\end{tabular}

LKQ ÁT = Low Back Pain Knowledge Questionnaire, általános tudás; LKQ F = Low Back Pain Knowledge Questionnaire, fogalmak; LKQ K = Low Back Pain Knowledge Questionnaire, kezelés; *szignifikáns érték

\section{A teszt-reteszt vizsgálat eredményei}

A kérdőív megbízhatóságát továbbá teszt-reteszt módszerrel vizsgáltuk, melyet a Spearman-féle korrelációs koefficiens meghatározásával számítottunk ki (2. táblázat). Itt a korrelációs koefficiens értéke $\mathrm{R}=0,541-$ 0,795-ig terjedt, mely mérsékelt és megfelelő összefüggést mutat az első és a második mérés eredményei között $(\mathrm{p}<0,050)$.
2. táblázat |Az LKQ teszt-reteszt vizsgálata Spearman-féle korrelációval

\begin{tabular}{lllll}
\hline & & LKQ_1 & LKQ_2 & LKQ_3 \\
\hline LKQ_1 & $\mathrm{R}$ & $0,650^{*}$ & & \\
& $\mathrm{p}$ & 0,001 & & \\
\hline LKQ_2 & $\mathrm{R}$ & & $0,541^{*}$ & \\
& $\mathrm{p}$ & & 0,001 & \\
\hline LKQ_3 & $\mathrm{R}$ & & & $0,795^{*}$ \\
& $\mathrm{p}$ & & & 0,000 \\
\hline
\end{tabular}

LKQ_1 = az LKQ-kérdőív 1. kérdéscsoportja, az általános tudásról; LKQ_2 = az LKQ-kérdőv 2. kérdéscsoportja a derékfájdalommal kapcsolatos fogalmakról; LKQ_3 = az LKQ-kérdőv 3. kérdéscsoportjai a derékfájdalom kezelésével kapcsolatban; $\mathrm{R}$ = korrelációs koefficiens *szignifikáns érték

\section{A Low Back Pain Knowledge Questionnaire és a Roland-Morris-indexek korrelációs vizsgálatának eredményei}

A Low Back Pain Knowledge Questionnaire és a RolandMorris-indexek összefüggéseit a Spearman-féle rangkorrelációs próbával elemeztük, amellyel az LKQ validitását vizsgáljuk. Eredményeink szerint a két kérdőív közepes szorosságú, szignifikáns összefüggést mutatott $(\mathrm{R}=$ $-0,393, \mathrm{p}<0,001$ ) (3. táblázat, 1 ábra). A negatív előjelü kapcsolat értelmezése szerint a betegek által megadott válaszok alapján az RMI-kérdőív szerint a gerinc funkcionális állapota minél rosszabb volt, a tudást felmérő kérdőív szerint a tudás annál nagyobb volt. Az életkorral és a legmagasabb iskolai végzettséggel összehasonlítva azt az eredmény kaptuk, hogy a magasabb végzettséggel nő $(\mathrm{R}=0,358, \mathrm{p}<0,001)$, a magasabb életkorral csökken $(\mathrm{R}=-0,194, \mathrm{p}<0,004)$ a betegségspecifikus tudás.
3. táblázat $\mid$ Az LKQ és a Roland-Morris-kérdőívek összefüggéseinek vizs- gálata az első deréktáji fájdalom idejével. Az életkorral és a leg- magasabb iskolai végzettséggel való korreláció Spearman-féle korrelációs elemzéssel

\begin{tabular}{lcc}
\hline & & Összpontszám LKQ ( $\mathrm{n}=218)$ \\
\hline Összpontszám_rm $(\mathrm{n}=168)$ & $\mathrm{R}$ & $-0,393^{*}$ \\
& $\mathrm{p}$ & 0,001 \\
& $\mathrm{p}$ & \\
\hline Első deréktáji fájdalom & $\mathrm{R}$ & $0,180^{*}$ \\
& $\mathrm{p}$ & 0,008 \\
\hline Életkor & $\mathrm{R}$ & $-0,194^{*}$ \\
& $\mathrm{p}$ & 0,004 \\
\hline Iskolai végzettség & $\mathrm{R}$ & $0,358^{*}$ \\
& $\mathrm{p}$ & $<0,001$ \\
\hline
\end{tabular}

Összpontszám_rm = a Roland-Morris-kérdőív összpontszáma (n = 168); Összpontszám LKQ = a Low Back Pain Knowledge Questionnaire összpontszáma $(\mathrm{n}=218)$ (Spearman-teszt)

*szignifikáns érték 


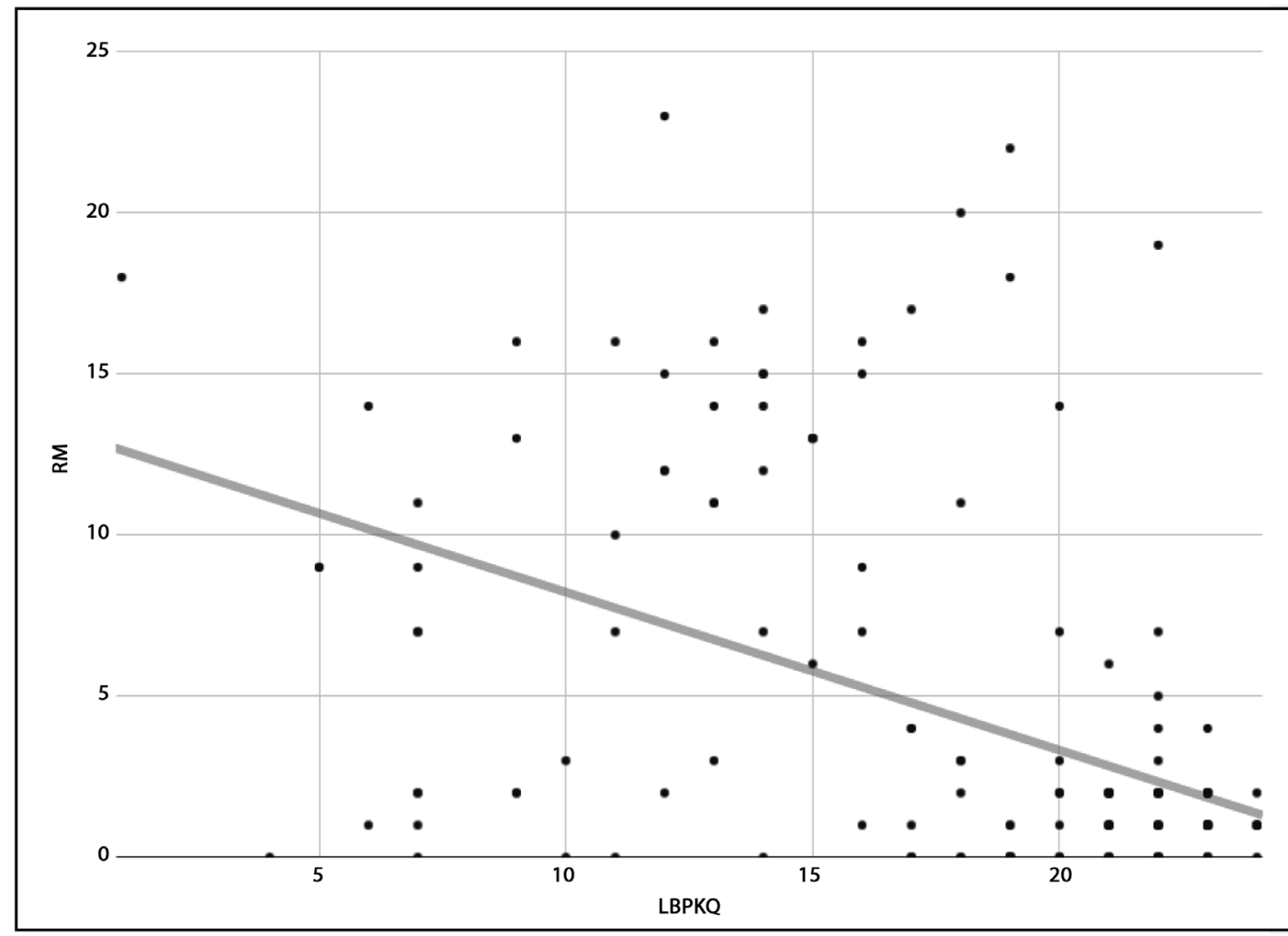

1. ábra

$\mid \begin{aligned} & \text { Az LKQ- és a R-M-kérdőív korrelációs kapcsolata } \\ & (\mathrm{x} \text {-tengely = a Low Back Pain Knowledge Questionnaire kérdőív értékei; y-tengely = a Roland-Morris-index értékei; R-M = Roland-Morris })\end{aligned}$

\section{A betegségspecifikus tudással kapcsolatos eredmények}

Az 54, gerinciskola-programon részt vett cLBP-beteg érte el a legmagasabb átlagösszpontszámot. Jobb eredményeik születtek, mint az 54 gerincmútöttnek és az 55 laikus résztvevőnek. Hasonlóan magas pontszámokat értek el, mint az 55 egészségügyi végzettségú résztvevő. Ezek az eredmények a kérdéscsoportok külön-külön való értékeléseinél is kirajzolódtak (4. táblázat).

\section{Megbeszélés}

A Low Back Pain Knowledge Questionnaire magyarra fordított verzióját, a Derékfájdalommal kapcsolatos betegségspecifikus tudást felmérő kérdőívet (DTK) megbízható és valid tudásmérô eszköznek találtuk a felmérés alapján.

Az összesen 108 cLBP-beteg közül a gerinciskolaprogramon részt vettek ( 54 fö) kiemelkedően magasabb betegségspecifikus tudással rendelkeztek. A laikus, krónikus LBP-szindrómát nem megélt résztvevő́k közel hasonló eredményeket értek el, mint a gerincmútéten átesett cLBP-betegek. Az egészségügyi végzettségúek jelentősen magasabb pontszámokat értek el a laikus és a gerincmútött betegek eredményeinél, a gerinciskolaprogramon részt vevőket azonban nem múlták felül. Az intenzív betegoktató program hatására a betegek idóle- gesen magasabb tudást mutattak, mint azok az egészségügyi dolgozók, akik aktívan nem ezen a területen dolgoztak, de képzésük során találkoztak az LBP témakörével. Az egészségügyi dolgozók által elért pontszám arra enged következtetni, hogy a magyarországi Porci Berci gyermek-gerinciskolaprogramhoz hasonlóan a felnőtt-gerinciskolaprogramhoz is szükség lehet egy posztgraduális képzésre.

\section{A kérdöív validálása}

Awwad és mtsai [7] szintén az LKQ-kérdőívet használták fel szaúd-arábiai betegek LBP-specifikus tudásának felmérésére 2015 decembere és 2016 februárja között. Az arab nyelvre fordítás, majd onnan az angolra való visszafordítás során sebészek is segítették a nyelvi validálást. A tudásmérő kérdő́iv mellett felmérték a betegek életkorát, nemét, családi állapotát, iskolázottságát és havi bevételük mennyiségét. Keresztmetszeti kutatásukba 18 és 75 év közötti non specifikus LBP-betegeket vontak be. A kérdőívet 153 beteg töltötte ki, átlagéletkoruk 40,2 év volt. A résztvevők neme és életkora alapján tett összehasonlítások nem mutattak szignifikáns kapcsolatot, de az iskolai végzettség és a havi kereset aránya befolyásolta a betegek tudását. Âtlagosan 9 pontot $(37,5 \%)$ értek el a kitöltők a 24-ból. A betegek túlnyomó része $(80,4 \%)$ nem talált összefüggést a krónikus derékfájdalom és az incontinentia, illetve a szexuális élet zavarai között. A kutatás azt 
4. táblázat $\mid$ Az LKQ-kérdőívvel mért betegségspecifikus tudás csoportonként

\begin{tabular}{|c|c|c|c|c|c|c|}
\hline Csoport & & LKQ-összpontszám & Összpontszám_rm & LKQ_at & LKQ_F & LKQ_K \\
\hline \multirow{2}{*}{$\begin{array}{l}\text { Gerinciskolai csoport } \\
(\mathrm{n}=54)\end{array}$} & Átlag & 22,28 & 1,41 & 8,7037 & 3,6415 & 9,9444 \\
\hline & Szórás & 1,309 & 0,813 & 0,63334 & 0,52236 & 0,78708 \\
\hline \multirow{2}{*}{$\begin{array}{l}\text { Gerincmütött betegek } \\
(\mathrm{n}=54)\end{array}$} & Átlag & 12,33 & 10,56 & 5,3704 & 1,3704 & 5,5926 \\
\hline & Szórás & 4,654 & 6,197 & 1,93572 & 1,15410 & 2,25304 \\
\hline \multirow{2}{*}{$\begin{array}{l}\text { Laikusok } \\
(\mathrm{n}=55)\end{array}$} & Átlag & 13,69 & & 5,4727 & 2,2778 & 5,9818 \\
\hline & Szórás & 5,040 & & 1,95178 & 1,30914 & 2,38429 \\
\hline \multirow{2}{*}{$\begin{array}{l}\text { Egészségügyi végzettségűek } \\
(\mathrm{n}=55)\end{array}$} & Átlag & 19,13 & 1,13 & 7,8000 & 3,4000 & 7,9273 \\
\hline & Szórás & 3,405 & 1,806 & 1,23828 & 0,78410 & 2,24313 \\
\hline \multirow{2}{*}{$\begin{array}{l}\text { Összesen } \\
(\mathrm{n}=218)\end{array}$} & Átlag & 16,85 & 4,34 & 6,8349 & 2,6713 & 7,3578 \\
\hline & Szórás & 5,583 & 5,755 & 2,10994 & 1,34279 & 2,65713 \\
\hline
\end{tabular}

LKQ_1 = az LKQ-kérdő́iv 1. kérdéscsoportja az általános tudásról; LKQ_2 = az LKQ-kérdőv 2. kérdéscsoportja a derékfájdalommal kapcsolatos fogalmakról; LKQ_3 = az LKQ-kérdőv 3. kérdéscsoportja a derékfájdalom kezelésével kapcsolatban; Összpontszám_rm: a Roland-Morris-kérdőív összpontszáma

mutatja, hogy a szaúdi betegek korlátozott tudással rendelkeznek az LBP-t illetően, és habár a magasabb iskolai végzettség magasabb tudásszintet vont magával, az a tudás még így sem volt megfelelőnek mondható. A betegoktató programok használatával a betegek figyelmét fel kell hívni az olyan tünetekre, amelyek azonnali orvosi, esetleg mütéti beavatkozást igényelnek. A kérdőív belső konzisztenciájának vizsgálatakor 0,834 Cronbach-alfaértéket kaptak, a mi eredményeinkhez hasonlóan $(0,894)$.

A betegségspecifikus oktatási programok és azok bevonása a betegek kezelésébe szoros összefüggésben áll a betegek tudásával, felkészültségével és a betegséggel való küzdelemmel, akár olyan súlyos betegségeknél is, mint a daganatok. Az EULAR (European League Against Rheumatism) nevü európai liga a reumatizmus ellen erősen ajánlja a gyulladásos arthritisszel élő betegek oktatását. Az ilyen oktatási programok hatékonyságának mérésére a betegek tudásának változását vizsgálhatjuk. Az Orlandi és mtsai által megalkotott [16] kérdőívet - „SPA: Mit tud róla?” - reumatológusok, gyógytornászok, ápolók és foglalkozási terapeuták szerkesztették. 14 kérdésből áll, melyekre 72 válaszlehetőséget adnak, közülük azonban csak 25 helyes. A kérdéseket négy csoportra lehet osztani: etiológia, tünetek, laboreredmények; öröklődés és immunológiai vizsgálat; gyógyszerek, gyógytorna; ízületvédelem, ergonómia. A kérdőív francia nyelvre történő fordítása és validálása után arra jutottak, hogy a francia lakosság nem rendelkezik megfelelő ismerettel erről a betegségről. Orlandinak és kollégáinak célja volt e kérdőívnek a brazil portugálra való fordítása és validálása. Továbbá vizsgálták, hogy a betegségspecifikus tudás mennyiben korrelál a betegek nemével, korával, iskolázottságával, foglalkozásával, a betegség fennállásának idejével, a diagnózis idejével és a gyógyszeres kezeléssel. A kérdőívet 60 beteggel töltötték ki, akik mindkét nemből reprezentálták magukat 18 és 65 év között. A fordítást két brazil anyanyelvi angoltanár végezte el, akik nem ismerték a kérdőívet, de tudták, hogy mi a kutatás célja. A brazil verziójú „SPA: Mit tud róla?” kérdő́vet sikerült reprodukálni, és korrelál az eredetivel, valamint az SF-36 kérdőív szociális és érzelmi részeivel. A kutatásban részt vevő betegek többségének nem volt főiskolai végzettsége. Összefüggést találtak a tudás szintje és a befejezett iskolák foka között. Statisztikailag szignifikáns eltérést találtak a tudás és a különböző etnikumok, valamint az iskolázottság között. A betegség fennállásának ideje és a betegségspecifikus tudás viszont nem mutatott szignifikáns kapcsolatot. A négy kérdéscsoportból az öröklődéssel kapcsolatos kérdéseket tudták a legkevesebben. A betegek viszont felismerték a testmozgás és a gyógytorna fontosságát a kezelés sikere szempontjából.

\section{A betegségspecifikus tudás összehasonlitása mások eredményeivel}

Maciel és mtsai [6] 2009-ben célozták meg egy betegségspecifikus kérdőív megalkotását a krónikus nonspecifikus derékfájdalomról. A 18 és 65 év közötti betegek a São Pauló-i reumatológiai klinikáról kerültek ki. Két csoportra osztottak 60, derékfájdalommal küzdő beteget, akik korábban nem kaptak betegoktatást. A vizsgálati csoport 4 héten át heti egy órában gerinciskola-programon vett részt, míg a kontrollcsoport várólistás betegekből állt. A betegek a kutatás minden fázisában a kérdések kevesebb mint 50\%-ára tudták a helyes választ. A kezelés témakörben jobb eredményeket értek el, mint az általános tudás és a fogalmak témakörben. A gerinciskola hatására relatíve javultak az eredmények. A program megkezdése előtt átlagosan 9 kérdésre válaszoltak helyesen, az oktatás végeztével ez a szám 16 helyes válaszra nőtt. A tudás bővítése nincs közvetlen hatással a klinikai állapotra, inkább közvetett hatást fejt ki az állapot fenntartására, a fájdalom kezelésére és az ízületvédelemre. Kérdőívük, a Low Back Pain Knowledge Questionnaire validnak, a változásra érzékenynek és megbízhatónak bizonyult. 
Kutatásukba Natour és mtsai 120 ápolót (60 ápolót LBP-szindrómával és 60, LBP nélküli ápolót) vontak be a São Pauló-i kórházból (Hospital São Paulo - Universidade Federal de São Paulo/Escola Paulista de Medicina) [17]. A dolgozók tudását a Maciel-féle LKQ-kérdőívvel mérték fel. Az ápolók mindkét csoportban a maximális 24 pontból átlagosan 19-et értek el. Az általános tudás témakörben 8 pontot, a derékfájdalommal kapcsolatos fogalmak terén 3 pontot, míg a derékfájdalom kezelését illetően 8 pontot értek el átlagosan. Az eredmények alapján arra lehet következtetni, hogy az ápolók a fontos ismeretek birtokában vannak, de ezeket a mindennapi gyakorlatban nem alkalmazzák.

$\mathrm{Az}$ ápolók magas kockázati csoportba tartoznak foglalkozásuk miatt a derékfájdalom kialakulása szempontjából. Cilliers és mtsai dél-afrikai ápolók tudását vizsgálták, valamint a derékfájdalom előfordulását, gyakoriságát és fennállásának idejét $[18,19]$. Kényelmi mintavétel segítségével 300 dolgozóval töltötték ki a kérdőívet keresztmetszeti, kvantitatív kutatásukhoz. Az ápolók 72\%-a már több mint 10 éve dolgozott a szakmában. Többségük, 84\%-uk szenvedett derékfájdalomtól az elmúlt hétben, valamint mindegyik, osztályon dolgozó ápoló szenvedett derékfájdalomtól az elmúlt évben, napi vagy heti szinten. Az esetek 78\%-ában 6 héten belül ez megoldódott. 19\%-uknál állt fenn a fájdalom 12 hétnél tovább is. $\mathrm{Az}$ ápolók többsége (46\%) a fájdalom jelentkezésekor orvossal vagy gyógytornásszal konzultál. A második leggyakrabban alkalmazott öngyógyítási elv (28\%) az ágy- nyugalom volt. Mindennapi feladatait 14\%-uk folytatta tovább. Már az első fájdalom megjelenésekor 12\%-uk gyógyszeres fájdalomcsillapítást választott. Az ápolók 54\%-a jelezte, hogy korábban már kapott tájékoztatást a derékfájdalmat illetően. A legtöbben ebben a témában az orvosokat, illetve gyógytornászokat tartották hiteles információforrásnak. Az okokat illetően a lágy szöveti húzódások, mechanikai problémák, a hosszan tartó állás, a hanyag testtartás, az előrehajlás szerepelt válaszaikban. A fájdalom eredetét $55 \%$-ban a betegek körüli feladatokban látják: emelés, betegmozgatás, ágyak/eszközök áthelyezése. A gyenge fizikai erőnlétet 20\%-uk tartotta felelősnek a derékfájdalomért. Az elhízást 72\%-uk tartotta oknak, míg a pszichológiai aspektusokat tekintve 58\%-uk a fáradtságot, $42 \%$-uk az érzelmi kimerülést és a depreszsziót tartotta fontos kockázati tényezőnek. 39\%-uk úgy tartotta, hogy minden fizikai aktivitást kerülni kell, míg a fájdalom el nem múlik. A résztvevőket megkérdezve arról, hogy mi szerepeljen egy prevenciós programban, az alábbi válaszokat kapták: hátizom-erősítő gyakorlatok, testsúlycsökkentési módszerek, emelőszerkezetek használata. Az ergonómiai ismereteket csupán 15\%-uk tartotta fontosnak ismerni.

\section{Következtetés}

Kutatásunkban azt az eredményt kaptuk, hogy a magyar betegek magasabb betegségspecifikus tudással rendelkeznek, mint a brazil vagy szaúd-arábiai cLBP-betegek.

5. táblázat |A betegségspecifikus tudáseredmények összehasonlítása más kutatások eredményeivel

\begin{tabular}{|c|c|c|c|c|c|}
\hline Szerző (évszám) & Vizsgált populáció & LKQ-összpontszám & LKQ ÁT & LKQ F & LKQ K \\
\hline $\begin{array}{l}\text { Maciel et al. } \\
(2009)\end{array}$ & $\begin{array}{l}30 \text { fó cLBP, átlagéletkor: } 46 \text { év, } \\
4 \text { hét gerinciskola; } \\
\text { Federal University of São Paulo }\end{array}$ & 16 & 5,9 & 2,3 & 7,8 \\
\hline $\begin{array}{l}\text { Maciel et al. } \\
(2009)\end{array}$ & $\begin{array}{l}30 \text { fó cLBP, átlagéletkor: } 46 \text { év; } \\
\text { Federal University of São Paulo; } \\
\text { nincs educatio }\end{array}$ & 8,6 & 3,7 & 0,9 & 4 \\
\hline $\begin{array}{l}\text { Awwad et al. } \\
(2017)\end{array}$ & $\begin{array}{l}153 \text { fó LBP, átlagéletkor: } 40 \text { év; } \\
\text { King Saud University }\end{array}$ & 9 & 3 & 1 & 5 \\
\hline Natour et al. (2018) & $\begin{array}{l}60 \text { fö LBP-s ápoló, átlagéletkor: } 31,7 \text { év; } \\
\text { Hospital São Paulo - Universidade Federal de } \\
\text { São Paulo }\end{array}$ & 19,2 & 8,2 & 3,1 & 8 \\
\hline Natour et al. (2018) & $\begin{array}{l}60 \text { fó nem LBP-s ápoló, átlagéletkor: 31,6 év; } \\
\text { Hospital São Paulo - Universidade Federal de } \\
\text { São Paulo }\end{array}$ & 19,1 & 8 & 3,1 & 8 \\
\hline A jelen felmérés & $\begin{array}{l}54 \text { fó cLBP-beteg, átlagéletkor: } 40 \text { év; } \\
\text { gerinciskola-oktatás }\end{array}$ & 22,2 & 8,7 & 3,6 & 9,9 \\
\hline A jelen felmérés & $\begin{array}{l}54 \text { fó cLBP beteg, átlagéletkor: } 42 \text { év; } \\
\text { nincs educatio, PTE KK Idegsebészeti Klinika }\end{array}$ & 12,3 & 5,3 & 1,3 & 5,5 \\
\hline A jelen felmérés & $\begin{array}{l}55 \text { fó laikus, átlagéletkor: } 37 \text { év; } \\
\text { nincs LBP, pécsi lakosok }\end{array}$ & 13,6 & 5,4 & 2,2 & 5,9 \\
\hline A jelen felmérés & $\begin{array}{l}55 \text { fó egészségügyi végzettséggel, átlagéletkor: } \\
22 \text { év; TE ETK- és pécsi egészségügyi dolgozók }\end{array}$ & 19,1 & 7,8 & 3,4 & 7,9 \\
\hline
\end{tabular}

LKQ_1 = az LKQ-kérdőív 1. kérdéscsoportja, az általános tudásról; LKQ_2 = az LKQ-kérdőv 2. kérdéscsoportja a derékfájdalommal kapcsolatos fogalmakról; LKQ_3 = az LKQ-kérdőv 3. kérdéscsoportja a derékfájdalom kezelésével kapcsolatban 
Maciel és mtsai kutatásában a gerinciskola-programban részt vett betegek átlagosan 16 pontot értek el, saját kutatásunkban a gerinciskola-programot követően 22,2 pontot szereztek a betegek. Oktatóprogram nélkül Maciel és mtsai, valamint Awwad és mtsai kutatásában ez a pontszám egyaránt 9 volt, jelen felmérésünkben 12,3 pont. A részcsoportokat illetően szintén magasabb pontszámokat értek el a betegek saját vizsgálatunkban. $\mathrm{Na}$ tour és mtsai vizsgálták még hasonlóan egészségügyi végzettségüek tudását az LKQ-kérdőívvel, ott a dolgozók átlagosan 19 pontot értek el. Saját kutatásunkban ugyanezt az eredményt tapasztaltuk. A kérdéscsoportok részeredményeit illetően szintén hasonló eredményeket kaptunk, mint Natour és mtsai a brazil felmérésükben (5. táblázat).

Vizsgálatunk hiányosságaként említenénk meg az alacsony elemszámot. Hipotéziseink szerint szerettünk vol- na több sportvégzettségü, illetve derékfájdalmat még nem megélt résztvevőt bevonni, de erre a jelen kutatás során nem került sor. Az eredeti kérdőív elsősorban a krónikus derékfájdalommal élők tudását célozza felmérni, jelen kutatásunkban a kitöltők közül 101 fó szenvedett aktuálisan cLBP-től. Nem akartuk azonban az akut vagy egészséges populációt kizárni, mivel úgy gondoltuk, hogy a kérdőív az LBP prevenciós tudásának mérésére is alkalmas. Eredményeink azt mutatták, hogy az akut és a derékfájdalmat nem megélt résztvevők tudását illetően is valid a kérdőív.

\section{Köszönetnyilvánítás}

Köszönetünket szeretnénk kifejezni ezúton is Prof. $D r$. Büki András klinikai igazgató úrnak és a PTE KK Idegsebészeti Klinika munkatársainak és betegeinek.

A jelen kérdőív célja, hogy felmérje az Ön derékfájdalommal kapcsolatos tudását. Kérjük, az egyes kérdésekben olvasható instrukció alapján jelölje a helyes vagy helytelen választ! Amennyiben nem tudja a választ, válassza a „Nem tudom” lehetőséget.

1) A gerincoszlop általános felépítése alapján jelöljön meg EGY helytelen választ!

a) Nyaki, mellkasi és ágyéki csigolyákból, valamint keresztcsontból épül fel.

b) Minden egyes csigolya közt található egy lengéscsillapító szerepet betöltő csigolya közti porckorong.

c) A csigolyák csatornát alkotnak, melyben található a gerincveló.

d) A hát- és hasizmoknak nincs szerepük a gerincoszlop megtartásában.

e) Nem tudom.

2) Mit nevezünk derékfájásnak? Jelöljön meg EGY helyes választ!

a) Az alsó bordák és a medence közt észlelhetó fájdalom.

b) Az alsó bordák és a medence közt észlelhetô fájdalom, amely a lábszáron keresztül a lábfejbe sugárzik.

c) A hát bármely területén érzékelhető fájdalom, a nyaktól egészen a csípőig.

d) Alhasi területen, a medence vagy a vese alsó részén érzékelhető fájdalom.

e) Nem tudom.

3) Mit nevezünk akut derékfájásnak? Jelöljön meg EGY helyes választ!

a) Az ágyéki gerinc fájdalma, amely kezeléstől függetlenül rendszerint három hét alatt elmúlik.

b) Kezelhetetlen fájdalom az ágyéki gerincszakaszon.

c) Mútéti beavatkozást igénylő ágyéki gerincfájdalom.

d) Több mint három hónapon át húzódó ágyéktáji fájdalom.

e) Nem tudom.

4) Mit nevezünk krónikus deréktáji fájdalomnak? Jelöljön meg EGY helyes választ!

a) Az ágyéki gerinc fájdalma, amely kezeléstôl függetlenül rendszerint három hét alatt elmúlik.

b) Kezelhetetlen fájdalom az ágyéki gerincszakaszon.

c) Mútéti beavatkozást igénylő ágyéki gerincfájdalom.

d) Több mint három hónapon át húzódó ágyéktáji fájdalom.

e) Nem tudom.

5) Mit nevezünk alsó végtagba kisugárzó fájdalomnak? Jelöljön meg EGY helyes választ!

a) Az alsó bordák és a medence közt észlelhető fájdalom.

b) Az alsó bordák és a medence közt észlelhető fájdalom, amely a lábszáron keresztül a lábfejbe sugárzik.

c) A hát bármely területén érzékelhető fájdalom, a nyaktól egészen a csípóig.

d) Alhasi területen, a medence vagy a vese alsó részén érzékelhető fájdalom.

e) Nem tudom.

6) Az alábbiak lehetnek a derékfájdalom kiváltó okai. Jelöljön meg KÉT helyes választ!

a) Öregedés, valamint hideg.

b) Testtartásbeli és ízületi problémák, porckorongsérv.

c) Daganatos betegség, fertőzés, törés.

d) Cukorbetegség.

e) Nem tudom. 
7) Az alábbiak lehetnek a derékfájás tünetei. Jelöljön meg KÉT helyes választ!

a) Köhögés, lomhaság, enerváltság.

b) Fáradékonyság, az egész testet átjáró fájdalom.

c) Ágyéktáji fájdalom, amely cipeléskor fokozódik.

d) Tárgyak talajról való felemelésekor jelentkező fájdalom.

e) Nem tudom.

8) Mi szükséges a derékfájdalom diagnosztizálásához? Jelöljön meg KÉT helyes választ!

a) Mágnesesrezonancia-képalkotás (MRI) és számítógépes tomográfia (CT) minden esetben szükséges.

b) Röntgenvizsgálat nem minden esetben szükséges.

c) A diagnózis felállítása a beteg kórtörténetén és fizikális vizsgálatán keresztül is gyakran lehetséges, további vizsgálatok elvégzése nélkül is.

d) Vércukor-, koleszterin-, valamint vizeletvizsgálat minden esetben szükséges.

e) Nem tudom.

9) A derékfájás gyógyszeres kezelésével kapcsolatban jelöljön meg EGY helytelen választ!

a) Akut fájdalom esetén gyulladáscsökkentó és fájdalomcsillapító gyógyszerek használata lehetséges.

b) Akut fájdalom esetén kortikoszteroidok használata lehet szükséges.

c) Krónikus derékfájás esetén izomlazítók és antidepresszánsok használata lehetséges.

d) Helyi kezelés, például gélek, tapaszok, kenőcsök használata minden esetben javallott.

e) Nem tudom.

10) Az akut derékfájás kezelésével kapcsolatban jelöljön meg KÉT helyes választ!

a) Egy hét szigorú ágynyugalom javasolt.

b) Határozatlan idejú betegszabadság szükséges.

c) A derékfájás akár kezelés nélkül is javulhat.

d) A lehetô legkevesebb pihenés ajánlott.

e) Nem tudom.

11) Mivel kezelhető a krónikus derékfájás? Jelöljön meg KÉT helyes választ!

a) Gyulladáscsökkentő gyógyszerek hosszú távú alkalmazásával.

b) Gerincvédelmi tanácsokkal és erősítő gyakorlatokkal.

c) Komoly fizikai igénybevétel esetén deréktartó öv viselésével.

d) Az elektroterápiás kezeléseknek (például rövidhullám, ultrahang, Bier-féle termoterápiás kezelés) nagyobb létjogosultságuk van, mint a célirányos izomerősítésnek.

e) Nem tudom.

12) A derékfájást és a fizikai aktivitást illetően jelöljön meg EGY helytelen választ!

a) Heti háromszori egy-egy órás séta jótékonyan hat a krónikus derékfájás panaszaira.

b) Akut derékfájás esetén intenzív testmozgás ajánlott.

c) Krónikus derékfájdalomtól szenvedő betegek számára a vízben végzett testmozgás jótékony hatású lehet.

d) A hasizmok, valamint a hátizmok erősítése a leginkább ajánlott gyakorlatok.

e) Nem tudom.

13) Mit tehetünk, hogy megóvjuk a gerincünket? Jelöljön meg KÉT helyes választ!

a) A legjobb módszer a hason történő alvás.

b) Üljünk le, amikor zokninkat vagy cipőnket szeretnénk felvenni.

c) Térdünk hajlítása nélkül hajoljunk le, amikor valamit fel szeretnénk venni a földről.

d) Mosogatáskor hasunkat támasszuk a mosogatónak.

e) Nem tudom.

14) Szintén gerincünk védelmével kapcsolatban, jelöljön meg EGY helytelen választ!

a) Ovatosan keljünk ki az ágyból, kezünk segítségével oldalra fordulva.

b) Kerüljük testünk egyenlótlen terhelését súlycipelés közben: két karunkra osszuk el a súlyt.

c) Kerüljük a gerinccsavaró mozdulatokat.

d) Egész napon át viseljünk magas sarkú cipőt.

e) Nem tudom.

15) Akut derékfájással kapcsolatban jelöljön meg KÉT helyes választ!

a) A betegek döntő többsége három hét alatt felépül.

b) A fájdalom elmúlását és a felépülést követően a beteget gyógyultnak tekintjük, nincsenek további kockázatok.

c) A gerinc megóvására tett javallatok betartása csak a tünetek jelentkezése során szükséges.

d) A visszaesés gyakori előfordulása miatt derékfájástól már szenvedett betegek számára a gerinc kímélésére vonatkozó javallatok betartása kötelező.

e) Nem tudom.

16) A derékfájás mútéti beavatkozással történő kezelésével kapcsolatban jelöljön meg KÉT helyes választ!

a) Néhány esetben indokolt.

b) Konzervatív kezeléssel nem múló ideggyöki nyomás, valamint a gerincoszlop instabilitása esetén szükséges lehet.

c) A mútéti beavatkozás garantált gyógymódot jelent derékfájás esetén.

d) Bármely típusú derékfájás esetén a legjobb megoldás.

e) Nem tudom. 
Anyagi támogatás: A közlemény megírása, illetve a kapcsolódó kutatómunka anyagi támogatásban nem részesült. A kutatást a GINOP 2.3.2-15-2016- 00047 projekt keretében végeztük.

Szerzői munkamegosztás: K.-B. B.: A kapott adatok feldolgozása, szakirodalmi kutatás, végkövetkeztetések. M. A.: A kutatás biostatisztikai számításainak elvégzése, helyességük ellenőrzése. Sz. B.: A kérdőív fordításának szakmai ellenőrzése. T. P., V. A.: Vizsgálati alanyok gyứjtése, a kérdőívek kitöltetése. R.-N. G.: A kérdőív fordításának szakmai ellenőrzése. Á. P.: A vizsgálati helyszín biztosítása, a vizsgálati engedély megadása. J. M.: Vizsgálati alanyok gyưjtése, a kérdőívek kitöltetése, kutatásmódszertani és szakmai ellenőrzés. A cikk végleges változatát valamennyi szerző elolvasta és jóváhagyta.

Érdekeltségek: A szerzőknek nincsenek érdekeltségeik.

\section{Irodalom}

[1] Beaton DE, Bombardier C, Guillemin F, et al. Guidelines for the process of cross-cultural adaptation of self-report measures Spine 2000; 24: 3186-3191.

[2] Kálcza-Jánosi K, Lukács A, Barkai L, et al. The validation of the Diabetic Knowledge Questionnaire on Transylvanian Hungarian population. [A Diabetic Knowledge Questionnaire (DKQ-24) validálása erdélyi magyar populáción.] Egészségtud Közl. 2013; 3: 91-98. [Hungarian]

[3] Tóth K, Tóthné Steinhausz V. The theoretics of back school. In: Tóthné Steinhausz V, Tóth K. (eds.) The back school program of the conscious sitting posture among primary school children. Additional back school programe to the schoolastic physical education. Gerinciskola elméleti tananyaga. In: Tóthné Steinhausz V, Tóth K. (szerk.) Tudatos ülés gerinciskolája általános iskolásoknak. Az iskolai testnevelésben végzendő tartáskorrekciót kiegészítő gerinciskola.] Pécsi Tudományegyetem, Egészségtudományi Kar, Pécs, 2015; pp. 91-122. [Hungarian]

[4] Weckbach S, Kocak T, Reichel H, et al. A survey on patients' knowledge and expectations during informed consent for spinal surgery: can we improve the shared decision-making process? $\mathrm{Pa}-$ tient Saf Surg. 2016; 10: 15 .

[5] Sharafkhani N, Khorsandi M, Shamsi M, et al. The effect of an educational intervention program on the adoption of Low Back Pain Preventive Behaviors in nurses: an application of the Health Belief Model. Global Spine J. 2016; 6: 29-34
[6] Maciel SC, Jennings F, Jones A, et al. The development and validation of a Low Back Pain Knowledge Questionnaire - LKQ. Clinics 2009; 64: 1167-1175.

[7] Awwad WM, Alfayez SM, Bin Dous AN, et al. Knowledge around back pain and spinal disorders among Saudi patients: a cross-sectional study. J Pak Med Assoc. 2017; 67: 1228-1231.

[8] Philadelphia Panel. Philadelphia Panel evidence-based clinical practice guidelines on selected rehabilitation interventions for low back pain. Phys Ther. 2001; 81: 1641-1674.

[9] van Tulder MW, Assendelft WJ, Koes BW, et al. Spinal radiographic findings and nonspecific low back pain: a systematic review of observational studies. Spine 1997; 22: 427-434.

[10] van Tulder MW, Scholten RJ, Koes BW, et al. Non-steroidal antiinflammatory drugs for low back pain. Cochrane Database Syst Rev. 2000; 2: CD000396.

[11] van Tulder MW, Malmivaara A, Esmail R, et al. Exercise therapy for low back pain. Cochrane Database Syst Rev. 2009; 2: CD000335.

[12] Airaksinen O, Hildebrandt J, Mannion AF, et al. European guidelines for the management of chronic non-specific low back pain, 2004. www.backpaineurope.org

[13] Heymans MW, van Tulder MW, Esmail R, et al. Back schools for non-specific low-back pain. Cochrane Database Syst Rev. 2004; 4: CD000261.

[14] Roland M, Morris R. A study of the natural history of back pain. Part 1: Development of a reliable and sensitive measure of disability in low back pain. Spine 1983; 8: 141-144.

[15] Ormos G, Czimbalmos Á, Csiki J, et al. The validation of two low back pain indexes in Hungary. [Két „derékfájás”-specifikus állapotfelmérő index hazai validálása.] Rehabilitáció 2014; 24 : 65-68. [Hungarian]

[16] Orlandi A, Braumi C, Jones A, et al. Translation to Brazilian Portuguese, cultural adaptation and reproducibility of the questionnaire "Ankylosing Spondylitis: What do you know?" Sao Paulo Med J. 2016; 134: 407-416.

[17] Morimoto HC, Jones A, Natour J. Assessment of gesture behavior and knowledge on low back pain among nurses. Adv Rheumatol. 2018; 58: 27.

[18] Betlehem J, Boncz I, Oláh, A. Tudományos közlések az egészségtudományban. Nővér. 2010; 6: 4-11.

[19] Ács P, Stocker M, Oláh A. The determination of economic and public health benefits achievable by increasing regular physical exercise. Apstract. 2013; 1: 5-14.

(Kovács-Babócsay Bianka, Pécs, Rét u. 4., 7623 e-mail: babocsaybianka@gmail.com)

A cikk a Creative Commons Attribution 4.0 International License (https://creativecommons.org/licenses/by/4.0/) feltételei szerint publikált Open Access közlemény, melynek szellemében a cikk bármilyen médiumban szabadon felhasználható, megosztható és újraközölhető, feltéve, hogy az eredeti szerző és a közlés helye, illetve a CC License linkje és az esetlegesen végrehajtott módosítások feltüntetésre kerülnek. (SID_1) 